Sebastián Mariano Giorgi*

\title{
The spectrum of subjectal forms: Towards an Integral Semiotics
}

https://doi.org/10.1515/sem-2018-0022

\begin{abstract}
What is the relationship between consciousness and semiosis? This article attempts to provide some clues to answer this question. For doing it, we explore the application of the Integral model to semiotics; that is to say, the metatheory that integrates the inside, the outside, the individual, and the collective dimension, on one hand and, on the other hand, the levels of development, states and types of consciousness. Our principal hypothesis is that the semiosis depends on the "subjectal" form where the self is located temporarily or permanently. To validate it, we analyze the way in which the universe of meaning changes between the self located below the subject (as a form), and the self located beyond of it. According to the Integral semiotics point of view outlined here, the relationship between consciousness and the meaning has to do with the reduction or expansion of the subjectal spectrum, and the trajectory of the self along of it.
\end{abstract}

Keywords: integral theory, integral semiotics, consciousness, semiosis, subjectal forms

\section{Introduction}

At present, there is a lot of development about perception (Petitot 2009; DarraultHarris 2009; Dissanayake 2009). Unfortunately, we find almost nothing about the role of consciousness (and its structures and states) in semiosis - with the exception of Jean-François Bordron (2012). However, there is much research about consciousness and its relationship to the brain in the neurosciences (Berlucchi and Marzi 2019; Chennu et al. 2009; Demertzi and Whitfield-Gabrieli 2016; Murillo 2005). Although there seems to be a consensus on the impossibility of reducing the mind to physical systems (an organ like the brain, for example), there is no

\footnotetext{
*Corresponding author: Sebastián Mariano Giorgi, Posgrado, Universidad de Buenos Aires, Buenos Aires, Argentina; and CLACSO, Buenos Aires, Argentina,

E-mail: transcomunicador@yahoo.com
} 
agreement on the precise relationship between them. So much so, that still cannot be explained the "emergence" of consciousness from complex systems.

Ken Wilber (2014) is the only one who has taken the first step towards an Integral Semiotics. We say the first step, because he just focuses on the Integral linguistics subject; more specifically, on the relationship between signs, their referents and their specific "worldspaces" of existence (see, e.g., Wilber 2014: 1-45 on this important subject). Sometimes, he even seems not to distinguish between referent and object. Actually, the object of study of semiotics is semiosis: the production and interpretation of sense. It is a more complex process than the relationship referent/sign. In addition, signs are just a level among others in the "hierarchy of levels of analysis" (Fontanille 2008) studied by semiotics. Thus, the latter cannot be reduced only to the study of a single level.

Nonetheless, the Integral metatheory (or even paradigm) has the categories to continue the path begun by Wilber because has the potential to show how "science, art, spirituality, and everything in-between provide valid insights that, when taken as a whole, provide the most complete view of human consciousness currently available" (Helfrich 2007). This approach could help us to better understand the consciousness from the perspective of semiotics, because it integrates levels of development, states and types of consciousness.

"Integral means balanced, inclusive, and comprehensive. When applied to a research methodology it means that one aspires to cover as many perspectives as possible" (Helfrich 2007). It is called "integral” because this model integrates four dimensions, aspects or planes of the human being, namely, the inside, the outside, the individual and collective. It is a metatheory because any theory can be analyzed from this same matrix or global perspective.

From what we have just said, we can explore the application of the integral matrix also to semiotics. To be precise, the semiosis that integrates the inside, the outside, the individual and the collective dimension, on one hand; and, on the other hand, the semiosis that integrates levels of development, states and types of consciousness. Figure 1 shows a graphic representation of it.

Explaining all the categories in Figure 1 exceeds the limits of this article. Grosso Modo, the left part of the diagram represents the individual/collective interior, and the right part is the exterior. The upper part is all related to individual development and the lower part is collective development. In the upper left we find all the different levels of consciousness that any individual may pass through in the full possibility of development to its fullest potential. In the upper right we find all the individual and physical aspects (e.g., brainwaves and behavior) associated with the upper left. In the lower left we find all the cultural and shared states of consciousness that any individual will 


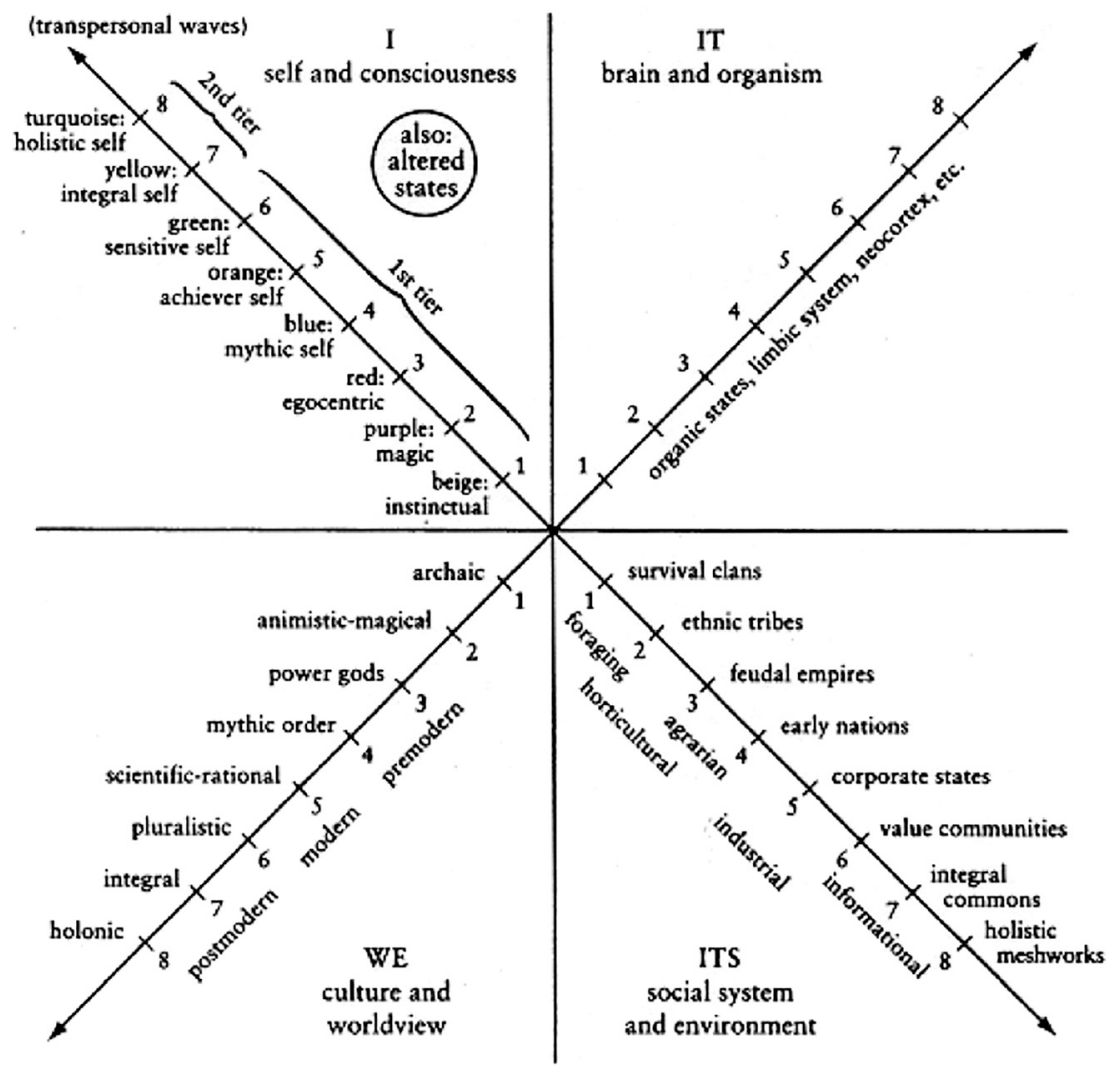

Figure 1: AQAL diagram.

be part of, and the stages of development that any group may pass through. In the lower right we see how the cultural values are reflected in different kinds of political and social systems.

From the theoretical framework of semiotics, we can place several schools and authors within one or several quadrants. To give some examples: sociosemiotics (in the lower right), Juri Lotman (in the lower left), psychosemiotics (in the upper left), human ethosemiotics and biosemiotics (in the upper right). So far none of them has integrated these four dimensions or perspectives. Hence the need for an Integral Semiotics.

The logic of the general plan of this article is to outline an epistemological framework characteristic of the Integral Semiotics. Then we will try to show the difference that exists between the semiosis located in a position previous to the 
construction of the subject, and the semiosis of a position located beyond the subject. Then we will outline the specific notion of "trans-subject" that we propose in this new semiotics. Later we will make a survey of some "soul technologies" that, according to our thesis, seek to build the "trans-subject" form. Then we will describe some features of border subjectal forms and positions. Then we will try to account for the expansion of consciousness from this new theoretical elaboration. A clue to understand it will be to analyze the relationship between form (subjectal) and the semiosis of that instance of origin. And to identify it, we will describe the different levels of analysis. The foregoing will allow us to distinguish the semiosis proper to the positions/forms anterior and posterior to those of the subject. Finally, we will analyze a story by Borges where the figure of the trans-subject appears. To finish, we will outline the characteristics of some trans-modalities that allow us to identify it.

\section{Epistemological framework}

According to the "Integral approach," there is an adjustment between mind, brain, culture, and social systems. Better known as AQAL - short for "all quadrants, all levels" - (see Figure 1), this model includes five main components, namely, a) levels of consciousness b) lines of consciousness, c) the four quadrants, d) types (of the "self" or "self-system") and e) states of consciousness. Not to exceed the limits of our article, we are going to focus on the last two.

Even though all the components of the psyche do not develop, there are, among them, those which do; and these elements (or phases) must be taken into account to better understand the semiosis. In line with this vision, we live in a universe whose currents of evolution appear to operate in the human mind. According to Wilber (2001a), there would abundant evidence of some evolutionary phases of cognition, ethics, psycho-sexuality, needs, objectal relations, motor skills, and language acquisition. However, these stages or levels are not linear nor rigid, but fluid as waves.

Wilber (2001a) uses three lexemes: "structures," "levels," and "waves" to describe events of the evolutionary process. For him, "structure" indicates a holistic pattern of each phase that articulates all its elements in a structured totality. "Level" means the tendency of these patterns to unfold in a relational sequence with a broader wave than previous ones, such as cells transcend but include molecules, such as molecules transcend but include atoms, such as atoms transcend but include quarks.

Finally, the sememe of "wave" has in his theory a certain character of fluidity and envelopment. As if it were concentric spheres of envelope, inclusion and 
increasing holistic capacity. Mutatis mutandis, it is the same principle of integration used by Jacques Fontanille (2008) when proposing the different "planes of immanence" and analytical relevance levels, but from the perspective of a Semiotics of cultures.

In accordance with the Integral theory, it is about levels of consciousness occupying the entire spectrum: from the unconscious to self-conscious; from the self-conscious to superconscious. In other words, what is revealed is continuity between different kinds of consciousness, and a new type of consciousness namely, "superconsciousness."

Wilber (2001a) points out that some modern and postmodern scholars accept the existence of matter, body and mind, but refuse, however, the soul and spirit. They prefer to think about levels of consciousness developing from a pre-conventional to another conventional to post-conventional levels. Unlike them, his approach accepts both the soul and the spirit and prefers to speak of a) pre-personal, through one of $b$ ) personal to that of c) "trans-personal" levels.

Our specific articulation between Wilber's theory and semiotics arises from the need to understand the relationship between "subjectal forms" (Giorgi 2012) and semiosis begun by the founder of psychosemiotics and human ethosemiotics, Ivan Darrault-Harris. His intention has been always to make compatibles the subjectal (Coquet 1984) with objectal (Greimas 1983) semiotics, the same as phenomenology with psychoanalysis. We start, then, with this transdisciplinary achievement of the ethosemiotics and we try to articulate it with the integral metatheory. Therefore, our approach is meta-transdisciplinary.

On the other hand, Fontanille's semiotical hierarchy transpolated from his Semiotics of practices serves to identify the levels of analysis. Just as the level of the signs differs from the level of the text-discourses, which, in turn, differs from the level of support objects and so on, subjectal forms have a logical presupposition and levels of integration between them. Also, as in Fontanille's semiotical hierarchy, in order to understand a level (i.e., texte-discourse), it is often necessary to go to a higher level of integration (like a subjectal form).

Our hypothesis holds that there are certain constructions of sense located in the beyond of the subject (as position). Consequently, it is necessary to broaden the spectrum of subjetal forms (or instances) to be able to interpret them accurately. To our knowledge, the only rigorous and non reductionistic approach which has dared to investigate the spectrum of consciousness and its manifestations, both ordinary and extraordinary, without falling into the pathologizing or childishness them, is the Integral theory. For this reason we decided to experiment with some of its categories and theoretical frameworks, with particular emphasis on Integral psychology, which can be defined as: 
... the study of human consciousness and its manifestations in behavior. The functions of consciousness include perceiving, desiring, willing and acting. The structures of consciousness, some facets of which can be unconscious, include body, mind, soul and spirit. The states of consciousness include normal (e.g., waking, dreaming, sleeping) and altered (e.g., nonordinary, meditative). The modes of consciousness include esthetic, moral, and scientific. The development of consciousness spans an entire spectrum from the prepersonal to personal to transpersonal, subconscious to self-consciousness to superconscious, id to ego to Spirit. The relational and behavioral aspects of consciousness refer to its mutual interaction with the objective, exterior world and the sociocultural world of shared values and perceptions. (Wilber 2000: 1)

\section{Below and beyond the subject}

We will take the thematic organization of the event held at the University of Limoges, on May 2011. It was a tribute day dedicated to the founder of human ethosemiotics ${ }^{1}$ and structured in three parts: presences/in the heart/beyond (of the subject). Let's start with one of the observations highlighted by Bordron, concerning the first component of the triptych: "One might wonder why there is not below of the subject, if the concept of the subject is truly something like a primitive form on which we could, somehow, be based" (symposium talk in 2011).

But his observation does not stop there. This is only an introduction to a central question of psychosemiotics, which is the existence and semiotical experience of consciousness. We share the same obsession with Bordron, that is to say, in the context of perception, "what guarantees the manifestation of subjectivity in the expression plane of the natural world? How is gradually being constructed something like a consciousness?" (symposium talk in 2011).

Although we are still far from giving satisfactory answers, we believe that after reading this article there will be some tracks. The first one is to return to the triptych division to formulate it otherwise: below (of the subject)/subject/beyond (of the subject). It goes without saying that the spaces of the "non-subject" (Coquet 1984: 63) and "quasi-subject" (Coquet 2007: 36) are in the first extreme end of the series. This, however, does not seem so obvious about the "actants" of the other extreme. We use the notion "actant" as Greimas (1966: 174-185) used to do, not only as a "structural role" but also structuring.

As we know, the first intervention is titled "Énonciation, schizie et paradoxes de presence. À propos du syndrome de l'X fragile” (Bertrand 2012: 19-28); it could be the object of biosemiotics, ethosemiotics or psychosemiotics. As we also

1 Most of the interventions exposed during this event are in the book published in honor of Ivan Darrault-Harris (Tsala Effa 2012). 
remember, the second intervention is devoted to the memorable book Pour une psychiatrie de l'ellipse (Darrault-Harris and Klein 2007), whose title is "Ivan Darrault-Harris, l'ellipe et l'enigme” (Fontanille 2012: 29-36). Both of them speak about different vicissitudes suffered by "quasi-subjects" to become subjects. If the first one, the most tragic, is condemned by the soma disorders to stay in the same place; the second (illustrated by clinical cases of Kathryn, Beatrice, and Yann) managed to occupy the next place (of the/subject/), through a strategical practice of changing known as "ellipse."

Unfortunately, and contrary to what seems obvious, the notion of "metasubject," as conceived by Coquet (1984), cannot come to our help for understanding this beyond. We are not going to fall into the temptation to change the content of this notion, because it is neither a "transcendental third actant" (e.g., the Society) nor immanent (e.g., the Freudian id). From the perspective of an Integral semiotics under construction, it has to do rather with a "trans-subject." That is an embodied and endowed actant with the capacity to overcome some social conventions (postconventional or post-postconventional) thanks to the development of trans-rational thought (a higher level of rationality).

\section{Bordering the trans-subject}

If one remains in the epistemology of "Subjectal Semiotics," even with the intention of expanding it into an Integral Semiotics, we should give to the trans-subject a modal definition. ${ }^{2}$ Hence, we must advance slowly and cautiously by saying that the trans-subject is above all a modalized subject by the power-Being.

This is a Being who is both transcendent and immanent - because It transcends the ego, because It is immanent to the being - which represents the expansion of consciousness beyond the language, beyond the subject/object duality, beyond the perception of space-time. It is about a folded Being into the being who acts as a Potential towards its realization.

It is about a Being who manifests itself through different "densities of presence," gradually as It unfolds in the being of each subjectal form. An unavoidable and infinite Being, eagerly sought in all religions and transcendentalists disciplines. A Being who operates as driving force, manifested in the expansion (so to complexity) of the universe and everything in it.

2 According to Subjectal Semiotics, what defines the subject is the possession of modalities (wanting, knowing, being able to do, etc.) and the presence of judgment. When these latter begin to disappear, the subject becomes a quasi-subject. When they are absent, the quasi-subject ends for becoming a non-subject. 
It has to do, for example, with the Homo sapiens as a driving force in the Pierolapithecus catalaunicus (proto-non-subject?). The latter is a new Middle Miocene (12.5-13 million years ago) ape. Its skeleton was discovered in Spain, and both his anatomy and age suggest that is "probably close to the last common ancestor of great apes and humans” (Moyà-Solà et al., 2004: 1339).

As we know, apes today include three African species, namely, a) the common chimpanzee (Pan troglodytes), b) the bonobo (Pan paniscus) and c) the gorilla (Gorilla gorilla) but also d) an Asian species, the orangutan (Pongopygmaeus).

This power-Being, necessary but not sufficient modality to become a transsubject, is (one of our hypotheses) a trans-modality. Let's remember the logic of the first definition of the semiotic subject made by Coquet:

... it is the ego that says ego (it is the linguistic act) and says oneself (or as one says) ego (it is the logical-semantic act). The ratio of these two proposals is the predication, namely a language use and the assumption of its use by an enunciating instance. (Coquet 1984: 15)

There is thus a "double [phenomena] supported by the ego a) of what he says or does, b) in the last instance, of itself, enunciating subject" (Coquet 1984). Hence the phrase: "I affirm that I am I," which does not come as much from the "wanting" as the "meta-wanting," because our author distinguishes between the presupposed enunciation and the utterance posed.

Although the logic seems impeccable and applicable to the subject (as a form or position), we argue that it is not enough for understanding the semiotic nature of the trans-subject form; because it is about the manifestation of phenomena located beyond the logic of language. Also, because not only the ego is expressed, but ego + Being without the drift of heteronomy or autonomy relationship. Instead, there is a fusion of one on the other beyond duality.

Going a little further, the tension between the Being and the being must be felt first, and, foremost, assumed. Accordingly, we consider that there is an evolution of the subjectal forms that results in a progressive presence of the Being into the being. However, there are exceptional states where this tension disappears for a few moments as those described by Stanislav Grof:

The holotropic states are characterized by a specific transformation of consciousness, associated with changes in perception in all sensory areas, powerful and often unusual emotions, and profound changes in thought process. Usually these states are also accompanied by a variety of intense psychosomatic manifestations and unconventional behavior. Consciousness is changed qualitatively in a very profound and fundamental way, but not grossly altered as is the case in delusional states. In holotropic states, we experience an intrusion into other dimensions of existence, intrusion that can be very deep and beyond us. However, we remain at the same time quite focused and not completely lose touch with ordinary reality. We experience simultaneously two [or more] very different realities. (Grof 1998: 10) 
When the Being is manifested in a subjectal form, there is a consciousness revolution because all other modalities manifest themselves simultaneously. We have already suggested that this Being belongs to another level of relevance more encompassing, but is also manifested in the previous level under various modalities of semiotic existence. We will define as "spirituality" this trajectory to realization of the Being in the being (which contains all modes).

\section{Technologies of the soul}

The paths are many and more or less effective. Some of them are exoteric (known by the majority of the population); some are mesoteric (known by a smaller number), while others are highly esoteric (which is only accessible to very few insiders). Spiritual practices are related to each culture (pre-modern, modern or postmodern) and there are strategies sometimes mystical hegemonic (as nowadays Christianism, Judaism, Islamism, Buddhism, Hinduism, Shintoism, Taoism, Shamanism, etc.), sometimes marginal (thus the "secret societies," defined with the lexeme/sects/heavily overloaded with afferent dysphoric semes).

To continue with the Czech psychiatrist, according to him these mental function alteration techniques have played a decisive role in the ritual and spiritual history of mankind. The induction of "holotropic states" (or trans-personal) was absolutely essential to shamanism, rites of passage and other ceremonies of native cultures.

The assumption of such non-ordinary states of consciousness allow some shamans to carry healing powers (trans-power) beyond any rational explanation (based on Aristotelian logic) or irrational (based on paradoxical or symbolic logic) because the individual unconscious is not enough to solve the enigma. Hence the interpretation of a "symbolic efficiency" (Lévi-Strauss 1949), although it is very powerful in some cases (like the song to help a difficult birth in the Cuna tribe, Panama), is no longer relevant.

Let's see another exemplary case of trans-subject under construction. The biographical film directed by Roger Christian (1994), where Tchéky Karyo plays the role of Nostradamus, shows a doctor whose avant-garde prophylactic methods (he takes a shower, burns the contaminated corpses and clothing by the plague) contrast with the dominant medical episteme of his time (late 1520). His scientific education does not become an epistemological obstacle to be interested in esotericism. Thanks to his travels and meetings with other scholars, he has access to knowledge forbidden by the powerful Holy Inquisition. Methods to alter consciousness, allow him to open the doors of the common perceptions and write a few prophecies (trans-knowing). The realization of some of them (especially the 
one about the day of the King Henry II's death) attracts the attention of Catherine de Medici, from whom receiving royal protection (Nostradamus 1568: 13).

\section{Border instances}

As there is a "border instance" (Coquet 2007: 36) between the non-subject and the subject, there also must be a quasi-trans-subject between the subject and the transsubject. An example could be someone who has the audacity to seek answers outside of any exoteric framework. In the extraordinary film directed by Peter Brook (1979), we discover the adventures of the young Gurdjieff (1969) during his initiatory path: the object of his epistemic quest is the "Truth." Through travels and meetings with numerous "remarkable men," he finds the tracks of a "collective actant" (the Sarmoung Brotherhood) which is supposed to have the power of giving accurate answers to inexplicable phenomena for conventional science and religions (exoteric).

In a dialog with a friend (who later becomes a monk), our hero confesses his unfulfilled "thirst for knowledge" despite having read many books. He specifically seeks the answer to the question “why am I here?” Gurdjieff later expresses the lack of something, as a feeling experienced since childhood, as another life to which did not know how to be opened. And this question does not let him have peace. Consequently, he becomes a "hungry dog" seeking the answer everywhere.

A psychologist formatted in orthodox psychoanalytic thought surely would advance explanatory hypotheses concerning the below of the subject, related to unconscious. The temptation is great because the figurative actor refers to his childhood and his desire, as if it were a bodily need, even animal (indomitable pulsion). In addition, the search for a sect whose esoteric knowledge (subject supposed to know) could answer to the question of the sense of life, would seem to come from the non-acceptance of castration. This would seem to have to do with magical thinking. In other words, it seems to have the features of a quasi-subject. However, we are inclined to perceive there a quasi-trans-subject who feels the call of the Being as irrational need (or pre-rational). Because he understands nothing for now, he can only feel it.

Another example could be someone who has extracorporeal experiences and is not satisfied with conventional responses that reduce the phenomenon into the dysfunction of the soma, or psychosis (among others), and decides to explore his experience otherwise. Such is the case of Robert Monroe, founder of the institute that bears his name, a pioneer in the application of sound technology (Hemi-Sync) to induce modify states of consciousness in laboratory conditions (see Monroe 1971: 19-31). 
That kind of experience allowed Monroe to evolve from the quasi-trans-subject form to the trans-subject one's, by comparing the data from his travels outside the physical body with observable empirical data. Before that, he crosses the moment of potentiality; the subject still hesitates between the assumption of his extracorporeal competence (trans-power) and his system of conventional beliefs. He had to go not only against the "common sense" (as an epistemological obstacle in the Bachelardian meaning), but also against the conventional scientific sense (postpostconventional).

It is likely that this confusion comes from the lack of categories to distinguish between the below and the beyond of the subject.

\title{
7 The expansion of consciousness
}

\author{
According to Integral psychology, consciousness
}

starts out largely autistic and undifferentiated from the material world. It then differentiates its bodily self from the material environment and emerges as an instinctive, impulsive self, but one that is still magically and animistically involved with the environment, and still struggling for egocentric power over the environment. [It would be between the non-subject and the quasi-subject] As the conceptual mind begins to emerge, it differentiates from the body, and thus the self adds increasingly mental capacities to its sensory ones, and hence begins to move out of the narcissistic, first-person, safety/security/power orbit and into more widely intersubjective, communal, and social circles. (Wilber 2000: 43-44)

Following the different stages of this process,

as rule thinking and the capacity to take the role of others emerge, egocentric gives way to sociocentric, with its initially conformist and conventional roles, mythic-absolutist beliefs, and often authoritarian ways [it would be the subject-form]. A further growth of consciousness differentiates the self from its embeddedness in sociocentric and ethnocentric modes, and opens it to formal, universal, worldcentric, postconventional awareness, which is an extraordinary expansion of consciousness into modes that are beginning to become truly global [we find here the quasi-trans-subject form]. (Wilber 2000: 44)

For Wilber (2000), this postconventional stance is deepened with post-formal development, which moves through relativistic individualism (where a belief in pluralism tends to lead to isolated, hyper-individualism) to global holism (which moves beyond pluralism to universal integration), so that the personal self becomes a more truly integrated, autonomous self. If consciousness continues its evolutionary spiral, it can stably move into transpersonal, post-postconventional realms (here is the trans-subject form). Figure 2 shows the spectrum of subjectal forms just described. 
It goes without saying that this model of the expansion of consciousness is based on a logical presupposition relationship. It is impossible to reach the transpersonal domains (of "enlightenment," for example) without going through the previous steps. However, there are kinds of temporary syncopations. But to investigate the issue, we must first understand the difference between state and structure.

As for the latter, the definition does not change much from what could provide structuralism (except that of Lacanian psychoanalysis, for which it is not possible to move from one structure to another one). Indeed, the definition is close to that of a dynamic structuralism. That is to say "holistic, self-organizing patterns with a recognizable code, regime, or agency” (Petitot 2004: 14). Regarding the state, it is a fleeting moment.

Now if we consider the forms of the subject's spectrum as "dynamic forms developing as wholes morphodynamicly (self) organized and (self) regulated" (without reducing them to a purely physical-natural dimension, but as wholes biopsycho-socio-cultural structuring). Each form presupposes the previous one: the trans-subject presupposes the quasi-trans-subject, which presupposes the subject, which presupposes the quasi-subject, which presupposes the non-subject.

And the self "surfs" from one extreme to the other of the spectrum. When it identifies with a form during its trajectory, the self is stabilized and becomes structure. It can also move and remain temporarily in each of the forms: sometimes regressively - regressions (when one becomes sick, for example); sometimes progressively - peak experiences (e.g., when performing a meditation); sometimes sequentially - non-subject $\leftarrow$ quasi-subject $\leftarrow$ subject $\leftarrow$ quasitrans-subject $\leftarrow$ trans-subject (e.g., when we fall asleep until deep sleep); sometimes through a syncopation - quasi-subject $\rightarrow$ trans-subject, etc. (e.g., as the mystical ecstasy felt by candidates for the shaman status among the BuryatAlares, studied by Garma Sandschejew [see Eliade 1968: 33 on this research]).

\begin{tabular}{|c|l|l|l|l|}
\hline \multicolumn{2}{|c|}{ Below } & Subject & \multicolumn{2}{c|}{ Beyond } \\
\cline { 1 - 1 } & & & Quasi-trans-subject & Trans-subject \\
\cline { 1 - 1 } & & & & \\
\hline Bodycentric & Egocentric & Sociocentric & Worldcentric & Kosmocentric $^{1}$ \\
\hline \multicolumn{2}{|c|}{ Pre-conventional } & Conventional & Postconventional & Post-postconventional \\
\hline \multicolumn{2}{|c|}{ Pre-rational } & Rational & \multicolumn{2}{|c|}{ Trans-rational } \\
\hline
\end{tabular}

Figure 2: Spectrum of subjectal forms. 


\section{Form and meaning}

Perhaps it should be emphasized that each state shall be interpreted according to the structure (or form) adopted by the self. It is indeed about the relationship between form and meaning.

Let's return to the example of the Buryat-Alares. We know that the quasisubject instance is pre-rational, in a magical and animistic relationship with the environment. Therefore, it is not so difficult to understand why the ecstatic experiences lived by the youth during the preparatory period and initiatory, are interpreted as the arrival of the ancestral spirits to take them to the Hell (see Eliade 1968).

If in the previous case there is a subject instance - or form - (then rational, conformist, conventional, with its mythical-absolutist and ethnocentric beliefs), the experience would probably be attributed to the effectiveness of prayer thanks to which the believer is closer to Allah, Jehovah, God, Krishna or to the divine presence of the chosen religion.

However, if the ecstasy happens through meditation or other spiritual technique (not necessarily religious) in a quasi-trans-subject form (then worldcentric, postconventional and trans-rational), the self could wonder about the source of ecstasy: is it an "oceanic feeling” (see, e.g., Freud 1992: 65 about this notion; therefore narcissistic [pre-rational origin])? Or is there actually something related to enjoyment of enlightenment (of consciousness [therefore from a trans-rational origin])?

\section{Levels of pertinence}

The central issue is the identification of the levels of pertinence to analyze, because we find the following hierarchy: the trans-subject transcends and includes the quasi-trans-subject, which transcends and includes the subject, which transcends and includes the quasi-subject, which transcends and includes the non-subject. Thus, each level (1+1) includes the instance (or form) of level (l) to its own principle of pertinence; like a Semiotics of practices. Although the latter is not integral, is integrative.

Claiming that one state includes another one necessarily seems to question the syntagmatic of transformations, and the specificity of each state: thus, according to Coquet (2007), the non-subject is "taken" by the world and the subject "retakes" this experience. In other words, one thing is to experience the world (so without rational judgment) and another thing is to talk about the experience of it (so with rational judgment).

However, what we try to show is the structural representation of the relationships of logic pre-supposition. As we have said before, it is impossible to 
arrive to the trans-subject as form without going through the previous forms of the spectrum, with the exception of temporary syncopations (to trans-personal states, holotropic or peak experiences).

Strictly speaking: in an evolutionary trajectory, the building of a trans-subject form as structure can only be achieved on the basis of a quasi-trans-subject infrastructure, which - in turn - will be built on subject infrastructure, and so on to the non-subject foundation. Table 1 illustrates what we have just outlined.

If we continue the analogy, the mystery of conversion from one form to another form is partially solved, because it is only the passage "between a level of substantial experience, firstly, and a plane of semiotic immanence, on the other" (Fontanille 2008: 19). This means that every form of the spectrum has a threshold, a horizon of experience, and a logic that characterizes each one from an "attractor center." Therefore, this is a coherent totality.

Below the threshold and beyond the horizon, the sense of the form, where we are located, returns to virtualization and potentialization. Meanwhile, the sense of the border forms begins to be actualized and realized. This would explain the fact that some "boundary" experiences can change an individual.

Thus the structural criterion of pertinence ensures the conversion that we have just explained. If the form becomes structure (i.e., this is not a temporary state of the self), then we return to the relationship between form and meaning. This allows us to apply the principle of integration, according to which what appears to be irrelevant in a level "l," becomes relevant at the level " $1+1$."

\section{The pre/sub - trans/pre confusion}

As we have seen, the structural criterion of pertinence can help us to distinguish the semiosis from different subject's forms, because what appears to be irrelevant at the non-subject or quasi-subject levels, it becomes relevant at the level of the subject. The "attractors" (Petitot 1989: 712-728) of them are respectively the body

Table 1: Correlations between thought, episteme, attractor and forms.

\begin{tabular}{llll}
\hline Thought & Episteme & Attractors & Forms (structures) \\
\hline Pre-rational & Pre-conventional & Bodycentric & Non-subject \\
& & Egocentric & Quasi-subject \\
Rational & Conventional & Sociocentric & Subject \\
Trans-rational & Postconventional & Worldcentric & Quasi-trans-subject \\
& Post-postconventional & Kosmocentric & Trans-subject \\
\hline
\end{tabular}


and the ego, whose episteme and thought are both pre-conventional and prerational. One example of this can be taken from the childhood.

According to Freud (1991), the child is absolutely selfish feels with maximum intensity needs and has a tendency to satisfy them without consideration of anyone and especially without worrying about the other children, his competitors. We must wait for the moral and altruistic feelings (i.e., the ability to put oneself in the place of others) are awakened in the little selfish. In the words of Theodor Meynert - cited by the father of psychoanalysis - we must wait for "a secondary self comes to cover and inhibit the primary self” (Meynert in Freud 1991: 260). In our categories: we must wait for the (generic) forms of non-subject/quasi-subject becomes a subject form (as a structure).

Following the line of reasoning above, we would be inclined to change the place of the Myrtha Chokler's (2012: 55-63) masterful presentation concerning the psychomotricity of the child. Instead of at the "heart of the subject," we would place it on the side of "below" the subject. We do not believe that the child is a "subject of action" (and not just reaction) but - if we can say - a quasi-subject of action who thinks with (pre-rational) logic related to his maturation.

Even if we agree with the hypothesis according to which the regulatory level of our behavior is the "narrativity" ${ }^{3}$ in small child there would be no subject of state 1 or subject of state 2, because there is not yet a subject. Although for Subjectal semiotics the subject is not abstract (on paper) but embodied (in flesh and bones), the spectrum of the child's self is restricted. As a form, he is quasi-subject; as a state, he can oscillate between non-subject and subject (thanks to the presence of other subjects). It may exceptionally be syncopation towards the more complex forms (quasi-trans-subject/trans-subject) as peak experiences.

To integrate the "states of consciousness" into semiotics, we should recall here the ethosemiotical notion of "subjectal position": as the instance (or form) where the "empirical subject" (Eco 1979) is at a given time. It could be justified not only due to this temporal trait, but also because "each enunciating instance models, on its own level, what can be called its universe of discourse” (Coquet 2007: 9); as well, "as it is about degrees of assumption or about adherence or about control or still about will, we are sent back to 'states of consciousness”' (Hagège 1985: 214).

The advantage of the notion of "subjectal position" lies in the fact that can give us a lead on the identity of the subject. That is to say: the form where the self is at a moment, whether it is an empirical subject or a "subject of paper." It means that this identity is not static but dynamic. "Obviously there is a correlation (at least a relationship) between instances, types (or forms) of subjects and degrees or states of consciousness" (Giorgi 2013: 30).

3 This is actually the hypothesis of the human ethosemiotics founded by Darrault-Harris. 
Going back to the childhood, let's see what happens in the movie The Sixth Sense (1999), where the subtlety of Manoj Shyamalan (2000) Nelliyattu is prodigious. The director hides to the spectator until the last minute, the both transrational faculty of the child (he sees the souls of the dead) and the actor died status (Bruce Willis) -who plays the "observer actant" 4 of the narrative.

What seems reasonable in the film is the diagnosis of Cole Sear (played masterfully by Haley Joel Osment) advanced by the psychologist: "he suffers from hallucinatory visions, paranoia, a form of childhood schizophrenia." Yet veridiction (epistemic order), far from following an Aristotelian logic (conventional) or paradoxical logic (pre-conventional [characteristic of the unconscious]), is on the side of beyond the subject.

Let's imagine a patient who tries to explain his difficulty to interact with the everyday world because of the deep inner transformation that he is living and defines as "supramental consciousness." When his orthodox psychoanalyst asks him for more details about this consciousness, the patient describes it as follows:

The supramental consciousness is not a fixed quantity but a power which passes to higher and higher levels of possibility until it reaches supreme consummations of spiritual existence fulfilling supermind as supermind fulfils the ranges of spiritual consciousness that are pushing towards it from the human or mental level. In this progression the body also may reach a more perfect form and a higher range of its expressive powers, become a more and more perfect vessel of divinity. (Ghose 1998: 539)

The psychoanalyst would probably believe to be in front of a psychotic event, but actually the patient is a philosopher, yogi, poet and an Indian spiritualist writer trying to adapt his trans-subjectal experience in the daily world life. This is an example of the confusion between trans-rational/pre-rational. While the transsubject is despised by Western science, it seems to be a privilege figure in fiction.

\section{The figure of the trans-subject in a text written by Borges}

A masterly example is the 1949 story entitled "La escritura del Dios" ('Writing of the God'), where the impeccable prose of Jorge Luis Borges (1999) tells the original story of Tzinacán, an ancient magician of the pyramid of Qaholom, enclosed in a stone prison with a jaguar. The cell is divided by the bars. The magician had been

\footnotetext{
4 Fontanille defines the observer as a "cognitive enunciative subject," as a "simulacrum by which the utterance will manipulate, through the statement itself, the enunciator's observation competence" (1989: 17).
} 
tortured by his Spanish captors, because they were seeking the confession of a hidden treasure.

Reduced to a powerless body, lying on the ground and in the darkness, he begins to recover the memory of his knowledge. He also searches of an ultimate and sacred word. In this mystical process, he enters into a dreamlike state where it is difficult to get out. Finally, he discovers the writing of God on the skin of the jaguar.

Despite having obtained the knowledge and power to break free from his imprisonment, to rebuild the Pyramid, to take vengeance on Pedro de Alvarado and his soldiers, Tzinacán decides not to pronounce the divine sentence because what happens to men is no more important to him: he is no longer Tzinacán, because he is no longer a man.

We will try to apply the categories already available on the corpus of the Argentinean writer.

I have lost count of the years I have lain in this darkness; I who once was young and could walk about this prison do nothing now but wait, in the posture of my death, for the end the gods have destined for me. With the deep flint blade I have opened the breast of victims, but now I could not, without the aid of magic, lift my own body from the dust. (Borges 1999)

A man who used to have a certain power over the others life (subject of power, thus a modalized subject), is imprisoned into a stone hole, in complete darkness, with an animal on the other side of the wall. He has lost the notion of time, and cannot even get up from the ground. He waits for his fatal fate in the position of a dead man (the one that the gods decided on for him). He is not anymore a subject, but a nonsubject because he is heteronomous and not modalized (he is completely resigned to his fate). "Driven by the inevitability of doing something, of somehow filling time, I tried, in my darkness, to remember everything I knew” (Borges 1999).

The non-subject begins to be modalized by the wanting (to remember what he knew): there are not many doubts, we are in front of a subject because he is being modalized and, for that reason, going out of the heteronomy towards the autonomy; in spite of his physical confinement, his desire of something (the knowledge, in this particular case) gets back.

\footnotetext{
One night I sensed that a precise recollection was upon me; before the traveler sees the ocean, he feels a stirring in his blood. Hours later, I began to make out the memory; it was one of the legends of the god. On the first day of creation, foreseeing that at the end of time many disasters and calamities would befall, the god had written a magical phrase, capable of warding off those evils. (Borges 1999)
}

The agitation in the blood of the traveler before seeing the sea is a beautiful analogy of the extrasensory perception (but less precise) of an imminent event, peculiar to the quasi-trans-subject. 
He wrote it in such a way that it would pass down to the farthest generations, and remain untouched by fate. No one knows where he wrote it, or with what letters, but we do know that it endures, a secret text, and that one of the elect shall read it. I reflected that we were, as always, at the end of time, and that it would be my fate, as the last priest of the god, to be afforded the privilege of intuiting those words. (Borges 1999)

Here we could wonder about the system of beliefs which models or shapes the intuitions of a trans-rational thought. We would thus return to the question of the relation between state and structure, between form and meaning. We could also yield to temptation "to pathologize" or "to primitivize" such a logic, considering the absence of notions (until now) to differentiate the semiosis elaborated by forms placed below and beyond the subject.

And at that, something occurred which I cannot forget and yet cannot communicate - there occurred union with the deity, union with the universe (I do not know whether there is a difference between those two words). Ecstasy does not use the same symbol twice; one man has seen God in a blinding light, another has perceived Him in a sword or in the circles of a rose. I saw a Wheel of enormous height, which was not before my eyes, or behind them, or to the sides, but everywhere at once. This Wheel was made of water, but also of fire, and although I could see its boundaries, it was infinite. It was made of all things that shall be, that are, and that have been, all intertwined, and I was one of the strands within that all encompassing fabric, and Pedro de Alvarado, who had tortured me, was another. In it were the causes and the effects, and the mere sight of that Wheel enabled me to understand all things, without end. (Borges 1999)

This untransferable experience, outside of language, about fusion with the Being, about ecstasy, of space-time abolition and hyper-understanding, seems a manifestation of transpersonal experience. Now the question is whether such a "holotropic state" becomes structure (transforming the instance of enunciation, becoming a trans-subject) or goes back in a previous subject-form (not-subject/ $\leftarrow$ quasi-subject $/ \leftarrow$ subject $/ \leftarrow$ quasi-trans-subject/ $\leftarrow$ trans-subject).

If we go back to Table 1, the instance or trans-subject form will not hesitate to conceive the existence of a Kosmic Intelligence, "lived" by some initiated people (with a trans-rational thought) with Whom one can be contacted through unconventional (or post-postconventional) methods. So for him, having lived such a holotropic state, it is likely that he interprets it as a contact with a more encompassing existence of frequency as that of space-time where his physical body exists.

A quasi-trans-subject, although accustomed to the trans-rational intuitions, will not go so far and will look for answers to such a state through his travels around the world, through the knowledge of different cultures, religions, sects, modified states of consciousness (that means post-conventional methods). 
Regarding the subject form, it is likely that for him such an experience only confirms the truth of the religion of the society to which he belongs (conventional episteme), the chosen people by the Being, Allah, Jehovah, God, Krishna, Buddha, etc., manifested.

As for the quasi-subject having lived a transpersonal state, he will have probably the invulnerable feeling of being exceptional; will claim to be worshiped by the others since he was chosen among mortals, even if cannot explain very clearly the reasons which authorize him to defend such certainty. Finally, the nonsubject will remain dumb, overwhelmed, a trembling body in trance.

To finish with the short story of Borges (1999), Tzinicán has just discovered the writing of God in the skin of the jaguar that was on the other side of the wall dividing the prison:

It is a formula of 14 random (apparently random) words, and all I would have to due to become omnipotent is speak it aloud. Speaking it would make this stone prison disappear, allow the day to enter my night, make me young, make me immortal, make the jaguar destroy Alvarado, bury the sacred blade in Spanish breasts, rebuild the Pyramid, rebuild the empire. 40 syllables, 14 words, and I, Tzinacán, would rule the lands once ruled by Moctezuma. But I know that I shall never speak those words, because I no longer remember Tzinacán. (Borges 1999)

The last paragraph ends saying:

Let the mystery writ upon the jaguars die with me. He who has glimpsed the universe, he who has glimpsed the burning designs of the universe, can have no thought for a man, for a man's trivial joys or calamities, though he himself be that man. He was that man, who no longer matters to him. What does he care about the fate of that other man, what does he care about the other man's nation, when now he is no one? That is why I do not speak the formula, that is why, lying in darkness, I allow the days to forget me. (Borges 1999)

These last paragraphs reveal the discovery of a trans-knowledge (the divine sentence) whose pronunciation would change the space-time, a trans-power of which a subject could use to become free and take revenge for the injustices committed by the conquistadors. Nevertheless, the enunciator decides not to exercise this transpower and remains in the darkness and oblivion.

Our explanatory hypothesis is that the transpersonal, holotropic experience had such a transformative power to the point of becoming structure: it is not any more about a subject, neither about a quasi-trans-subject but a trans-subject.

We are convinced that among semioticians there will be those who strongly resist these new categories, and prefer another explanatory hypothesis namely, in the reality of the fiction, it is only about a psychosis. Again, we would be faced with the confusion between below and beyond the subject as a form. 


\section{Trans-modalities}

Concerning the trans-modalities, Stanislav Grof (1998) asserts that scientists with indisputable references such as Joseph Banks Rhine, Gardner Murphy, Jules Eisenbud, Stanley Krippner, Charles Tart, Elmer and Alyce Green, Arthur Hastings, Russell Targ, and Harold Puthoff, have already accumulated sufficient proofs of the existence of telepathy, clairvoyance, out-body-experience, remote vision, diagnosis and psychic healing (in the paranormal sense of the lexeme), or the psychokinesis which can bring data for a new understanding of reality.

Grof (1998) also adds that it is interesting to notice the fact that several contemporary physicists familiar with quantum-relativist physics show an interest in the paranormal phenomena, unlike traditional psychiatrists and psychologists.

For his part, Wilber (2001b) argues that the West has repressed transcendence for centuries. According to him, this is the origin of much of the unhappiness of civilization today. Therefore, the return of what was repressed appears under different symptoms like rash of interest in meditation, psychic phenomena, yoga, Eastern religions, altered states of consciousness, biofeedback, out-bodyexperiences and near-death-experiences.

To finish, we are going to quote William Braud's (1995) observations concerning the relationship between science and spirit. For him, there is no need for science to justify the spirit. Nor can it do so.

As suggested long ago by Hugo of St. Victor and Bonaventure, and elaborated by Ken Wilber, there are at least three realms of being and three ways of accessing these realms. 1 There is a physical, sensory realm accessed by the eye of the flesh; a mental realm of ideas, thoughts, and images perceived by the eye of the mind; and a transcendental or spiritual realm known through the eye of the spirit. Each eye reveals a different aspect of reality, and what is revealed to one eye is not necessarily available to the others. Wilber reminds us that we commit category errors when we unwisely attempt to see everything through one eye only and allow one form of vision to usurp the domains of the other two. To approach a complete picture of reality, we must have, at least, triple-vision. (Braud 1995: 36)

\section{Conclusions}

To conclude, we can say that the Integral semiotics does not need to justify the Spirit. Nor can it do so. Nevertheless, it should at least provide the necessary tools to understand the semiosis of the whole spectrum of subjectal forms. It is also possible that other forms may appear to widen the spectrum. 
We have pointed out the difference between structures and states, in order to help us not to confuse any more the semiosis from the below with the semiosis from the beyond the subject. We have seen that we cannot do it only identifying the worldspace of referent and subject, because the identity of the (empirical or fictional) subject is more complex than that and is neither static, nor stable.

Finally, the semotical experience of consciousness seems to be associated with both the expansion and contraction trajectory of the self, and the acquisition or loss of modalities. The more the self acquires modalities, the more possibilities has the Being to actualize Its potential.

\section{References}

Berlucchi, Giovanni \& Carlo Alberto Marzi. 2019. Neuropsychology of consciousness: Some history and a few new trends. Frontiers in Psychology 10. 50.

Bertrand, Denis. 2012. Énonciation, schizie et paradoxes de présence. À propos du syndrome de I'X fragile. In Actes du colloque en hommage à Ivan Darrault-Harris, Limoges, 6 mai 2011, 19-28. Limoges: Lambert-Lucas.

Bordron, Jean-François. 2012. Perception et conscience: Quelques 33 aperçus sémiotiques. Intellectica 58(2). 33-51.

Borges, Jorge Luis. 1999. The writing of the god. In Andrew Hurley (trans.), Collected fictions, 566-577. London: Penguin.

Braud, William. 1995. Parapsychology and spirituality. Implications and intimations. ReVision: $A$ Journal of Consciousness and Transformation 18(1). 36-43.

Brook, Peter (dir.). 1979. Meetings with remarkable men [DVD]. Sandpoint, ID: Morning Light Press. Chennu Srivas, Craston Patrick, Wyble Brad \& Bowman Howard. 2009. Attention increases the temporal precision of conscious perception: Verifying the neural-ST2 model. PLoS Computational Biology 5(11). e1000576.

Chokler, Myrtha. 2012. Salut aux convergences!. In Darrault-Harris, Ivan, \& Didier Tsala Effa (eds.), Une semiotique du subjet. Actes du colloque in hommage à Ivan Darrault-Harris, Limoges, May 6, 2011, 55-63. Limoges: Lambert-Lucas.

Christian, Roger (dir.). 1994. Nostradamus [DVD]. Los Angeles: Orion Classics.

Coquet, Jean-Claude. 2007. Phusis et logos: Une phénoménologie du langage. Saint-Denis: PUV. Coquet, Jean-Claude. 1984. Le discourset son sujet, vol. 1. Paris: Klincksieck.

Darrault-Harris, Ivan. 2009. Non-genericity as an invariant of the readability of pictures. Cognitive Semiotics 5. 93-102.

Darrault-Harris, Ivan \& Jean-Pierre Klein. 2007. Pour une psychiatrie de l'ellipse: Les aventures du sujet en creation. Paris: PUF.

Demertzi, Athena \& Susan Whitfield-Gabrieli. 2016. Intrinsic brain activity and consciousness. In Giulio Tononi \& Steven Laureys (eds.), The neurology of conciousness: Cognitive neuroscience and neuropathology, 2nd edn., 95-105. San Diego: Academic Press. 
Dissanayake, Ellen. 2009. The artification hypothesis and its relevance to cognitive science, evolutionary aesthetics, and neuroaesthetics. Cognitive Semiotics 5. 136-158.

Eco, Umberto. 1979. Lector in fabula. Milan: Bompiani.

Eliade, Mircea. 1968. Le chamanisme et les techniques archaïques de l'extase. Paris: Payot. Fontanille, Jacques. 2008. Pratiques sémiotiques. Paris: PUF.

Fontanille, Jacques. 2012. L'ellipse et l'énigme Ivan Darrault-Harris. In Darrault-Harris, Ivan, \& Didier Tsala Effa (eds.), Une semiotique du subjet. In Actes du colloque in hommage à Ivan Darrault-Harris, Limoges, May 6, 2011, 29-36. Limoges: Lambert-Lucas.

Freud, Sigmund. 1991. La interpretación de los sueños. In James Strachey (ed.), José Luis Etcheverry (trans.), Obras completas, vol. 4. Buenos Aires: Amorrortu.

Freud, Sigmund. 1992. El malestar en la cultura. In James Strachey (ed.), José Luis Etcheverry (trans.), Obras completas, vol. 21. Buenos Aires: Amorrortu.

Ghose, Aurobindo. 1998. Essays in philosophy and yoga. Pondicherry: Sri Aurobindo Ashram. Giorgi, Sebastián Mariano. 2012. Le spectre des formes du sujet. In Actes du colloque en hommage à Ivan Darrault-Harris, Limoges, 6 mai 2011, 121-139. Limoges: Lambert-Lucas.

Giorgi, Sebastián Mariano. 2013. Organisation et réception du discours cinématographique: L'analyse d'un film de Wilson Yip: L'esquisse d'une sémiotique intégrale. Université de Limoges PhD thesis.

Greimas, Algirdas Julien. 1966. Sémantique structurale: Recherche et méthode. Paris: Larousse. Greimas, Algirdas Julien. 1983. Du sens II: Essais semiotiques. Paris: Editions du Seuil.

Grof, Stanislav. 1998. The cosmic game: Explorations of the frontiers of human consciousness. New York: State university of New York press.

Gurdjieff, Georges Ivanovitch. 1969. Meetings with remarkable men. New York: E. P. Dutton. Hagège, Claude. 1985. L'homme de paroles. Paris: Fayard.

Helfrich, Paul M. 2007. Ken Wilber's model of human development: An overview v. 5.0. https://www.paulhelfrich.com/library/Helfrich_P_The_Five_Phases_of_Wilber.pdf (accessed 15 July 2020).

Lévi-Strauss, Claude. 1949. L'efficacité symbolique. Revue de l'histoire des religions 133(1). 5-27. Monroe, Robert. 1971. Journeys out of the body. New York: Doubleday.

Moyà-Solà, Salvador, Meike Köhler, David M. Alba, Isaac Casanovas-Vilar, Jordi Galindo. 2004. Pierolapithecus catalaunicus, a new Middle Miocene great ape from Spain. Science 306(5700). 1339.

Murillo, Alejandro. 2005. Conciencia, cerebro y neurociencia: Parte I. Breve panorama del debate. Saga 6(12). 71-79.

Nostradamus. 1568. Les prophéties de M. Michel Nostradamus. Lyon: Rigaud.

Petitot, Jean. 1989. Forme. Universalis. 712-728. https://www.universalis-edu.com.ezproxy. unilim.fr/encyclopedie/forme/ (accessed 10 March 2016).

Petitot, Jean. 2004. Morphologie et esthétique: La forme et le sens chez Goethe, Lessing, LéviStrauss, Kant, Valéry, Husserl, Eco, Proust, Stendhal. Paris: Maisonneuve \& Larose.

Petitot, Jean. 2009. Non-generic viewpoints as a method of composition in Renaissance paintings. Cognitive Semiotics 5. 7-41.

Shyamalan, M. Night (dir.). 2000. The sixth sense [DVD]. Los Angeles: Hollywood Pictures Home Video. 
Tsala Effa, Didier (ed.). 2012. Actes du colloque en hommage à Ivan Darrault-Harris, Limoges, 6 mai 2011. Limoges: Lambert-Lucas.

Wilber, Ken. 2000. Integral psychology: Consciousness, spirit, psychology, therapy. Boston/ London: Shambhala.

Wilber, K. 2001a. The eye of spirit: An integral vision for a world gone slightly mad. Boston: Shambhala.

Wilber, Ken. 2001b. No boundary. Eastern and Western approaches to personal growth. Boston: Shambhala.

Wilber, Ken. 2014. Integral semiotics. https://www.kenwilber.com/writings/read_pdf/117 (accessed 13 July 2016). 